\title{
The Impact of Social Media Marketing on the Success of Small-Sized Enterprises in Jordan
}

\author{
Ala'a Mansour Khresat ${ }^{1 *} \quad$ Nour Marwan qtaishat ${ }^{2}$ \\ 1.School of Management Information System, Al-Balqa' Applide University, P.O Box 19117,Faculty Salt \\ College, Salt, Jordan \\ 2.School of Marketing,Al- Balqa' applide University, , Salt, Jordan
}

\begin{abstract}
The present study aimed to explore the impact of using social media as marketing tool on the success of smallsized enterprises in Jordan. The study's population consists from all the owners of small restaurants located in Jordan, Amman. As for the sample, it consists of (100) owners who are selected from the population. The questionnaire sheds a light on (e-infrastructure, having a social media page, and human resources).It was found that the owners of small restaurants in Jordan have positive attitudes towards using social media as a marketing tool. It was found that using social media as a marketing tool has a statistically significant impact on the success of small-sized enterprises in Jordan. It was found that having a social media page has a statistically significant impact on the success of small-sized enterprises. It was found that e-infrastructure and human resources don't have any statistically significant impact on the success of small-sized enterprises. The researcher recommends developing the e-infrastructure in Jordan.
\end{abstract}

Keywords: E-Marketing, Social Networks, Small-sized enterprises

DOI: $10.7176 / \mathrm{IKM} / 9-6-03$

Publication date:June $30^{\text {th }} 2019$

\section{Introduction}

Technological developments have been increasing. In addition, the intensity of the competition has been increasing too. Thus, owners of enterprises have been using social media for advertising their products online. The use of social media as a marketing tool enable the owners of small-sized enterprises to compete with the owners of big-sized enterprises. Through using social media as a marketing tool, companies have become able to display their products before customers. Through social media, customers have become able to order products electronically (Al-Obaidi et al., 2011).

The use of social media has been increasing. Therefore, companies have been using social media for identifying the customers' needs in order to meet them. Companies have using social media in order to keep up with the latest developments. Social media can be used by any one for advertising his/her products (ElAydi, 2018).

E-commerce simply refers to the use of the World Wide Web for exchanging information between companies and their customers about products and services. It also involves ordering a product online (Belkasem and Ali, 2003). The use of social media as a marketing tool has enabled companies to gain more profits. The use of social media as a marketing tool has many advantages, such as: (Dahmash and Qashi, 2004):

The use of social media as a marketing tool enables the owners of enterprises to save costs. For instance, using conventional advertising means is considered costly. Such conventional means may include: TV, newspaper, and etc..

Through using social media as a marketing tool, companies can reach out to customers in various places of the world. That shall enable companies to gain loyal customers outside the country it is located at without incurring additional costs.

People can use social media for advertising their products without having to open a new branch which requires getting a license.

Social media marketing is a marketing strategy (ElAydi, 2018). McKinsey (2007) defines social media marketing as the process of using social media websites for retraining customers, gaining new customers, communicating with customers and selling products.

AL-Jamal (2015) states that social media emerged as a result of the technological developments. He adds that social media enables people to communicate regardless of how far they are from each other. For instance, people can text each other through using social media websites

\section{Statement of the Problem}

Big-sized companies must advertise their products. However, advertising products through conventional means is considered costly for the owners of small-sized enterprises. Thus, marketers must identify modern marketing means that are considered effective and capable of saving the costs incurred by the owners of small-sized enterprises. Such modern marketing means include social media. In the light of that, the researcher of the 
present study aimed to answer the following questions: (What is the impact of social media marketing on the success of small-sized enterprises in Jordan?).

\section{The Study's Significance}

The present study is considered significant. That's because the present study shall provide recommendations that enable the owners of small restaurants in Jordan to benefit more from social media. Such recommendations shall enable those owners to use social media effectively for advertising their products. It should be noted that most of the similar studies focus on big-sized enterprises. In other words, researchers didn't provide adequate attention to the use of social media as a marketing tool by the owners of small-sized enterprises. Thus, the present study fills a gap in the relevant literature.

\section{The Study's Questions}

The present study aimed to: Identify the meaning of social media marketing

Explore the impact of social media marketing on the success of small-sized enterprises in Jordan

\section{The Study's Hypotheses}

The researcher developed the following hypotheses

The Main Hypothesis:

Ha. Social media marketing has a statistically significant impact on the success of small-sized enterprises in Jordan

The Sub-hypotheses:

H1: The e-infrastructure has a statistically significant impact on the success of small-sized enterprises in Jordan $\mathrm{H} 2$ : Having a social media page has a statistically significant impact on the success of small-sized enterprises in Jordan

H3: Human resources have a statistically significant impact on the success of small-sized enterprises in Jordan.

\section{Review of Literature}

ElAydi (2018) aimed to explore the impact of social media marketing activities - that are performed through Facebook -on brand awareness in Egypt. The examined dimensions of social media marketing are: online communities, interaction, sharing content, accessibility, and credibility. The study's sample consists from 402 customers. The latter researcher tested the study's hypotheses through conducting correlation analysis, and regression analysis and using the SPSS program. He also used the structure equation model and AMOS. It was found social media marketing activities - that are performed through Facebook - have a significant impact on brand awareness in Egypt.

Florez et al (2018) aimed to explore the factors that motivate young university students to use social media for purchasing products. A questionnaire was used for collecting data. The questionnaires forms were distributed to 224 university students. It was found that the amount of knowledge provided through social media shall affect the respondents' decision to use social media for purchasing products.

Benea (2014) aimed to explore the impact of using social media as a marketing tool by Viennese hotels on the extent of meeting the business goals. It was found that marketers in Viennese hotels aren't concerned in the extent of meeting the financial goals when using social media as a marketing tool. In fact, they are concerned in the extent of meeting the goals related to customer satisfaction, and engagement, and brand awareness.

Al-Obaidi et al. (2011) aimed at exploring the impact of e-marketing on the marketing costs at Zain Telecommunication Company in Jordan. It was found that e-marketing can reduce the marketing costs and salaries incurred by the latter company. It can also reduce the number of training courses that must be provided to the employees working at the marketing department at Zain Telecommunication Co. 
The Study's Variables

Independent variable: Social media marketing.

Dependent variable: Success of small-sized enterprises

The Study's Model:

\section{Social Media Marketing}

1. E-infrastructure Having a

social media page

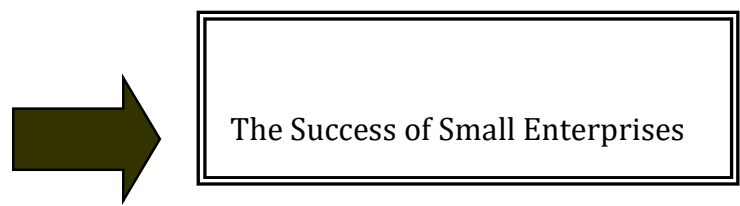

2. Human resources

\section{Data Analysis}

Data was collected through using a questionnaire. The collected data was analyzed statistically through using the SPSS program. Descriptive analytical methods were used. In addition, the study's hypotheses were tested

The Study's Population and Sample:

The study population consists from all the owners of Jordanian small restaurants. As for the sample, it consist of (100) individuals who were selected from the study's population

Descriptive Statistical Analysis:

Five points Likert scale was adopted and the SPSS program was used for analyzing data. Means and the standard deviations were calculated. The scale consists from the following rating levels and scores: (5) Fully Applied, (4) Good, (3) average, (2) Partially, (1) Poorly.

The average of means is calculated as follows: $(5+4+3+2+1 / 5)=3$. Thus, if the mean is greater than 3 , it shall be considered positive. If the mean is less than 3 , it shall be considered negative.

Table (5): Result related to e-infrastructure

\begin{tabular}{|l|l|l|}
\hline Statement & Mean & S.D \\
\hline $\begin{array}{l}\text { It's necessary to develop the electronic infrastructure for enabling people to practice e- } \\
\text { commerce and conduct online business transactions }\end{array}$ & 3.67 & .620 \\
\hline $\begin{array}{l}\text { Having an electronic infrastructure is essential for using social media for marketing } \\
\text { goals }\end{array}$ & 3.15 & .435 \\
\hline $\begin{array}{l}\text { Having an excellent electronic infrastructure shall increase the number of internet } \\
\text { users. It shall create a suitable environment for practicing e-commerce }\end{array}$ & 3.29 & .456 \\
\hline The accessibility to Internet affects the use of social media for marketing goals & 3.36 & .731 \\
\hline $\begin{array}{l}\text { The extent of practicing e-commerce is affected by the availability and accessibility of } \\
\text { personal computers, phones and computers host }\end{array}$ & 3.37 & .597 \\
\hline $\begin{array}{l}\text { Practicing e-commerce through making internet calls provides a suitable business } \\
\text { environment }\end{array}$ & 3.67 & .652 \\
\hline
\end{tabular}

Based on table (5), the owners of small restaurants in Jordan have positive attitudes towards the role of the e-infrastructure in achieving success for small-sized enterprises

Table (6): Results related to having a social media page

\begin{tabular}{|l|l|l|}
\hline Statement & Mean & S.D \\
\hline Having a social media page representing the company is very important & 3.67 & .620 \\
\hline $\begin{array}{l}\text { The presence of a social media page plays a significant role in advertising the } \\
\text { company's products }\end{array}$ & 3.17 & .377 \\
\hline $\begin{array}{l}\text { The owners of small enterprises must make a social media page to encourage people } \\
\text { to buy their products electronically }\end{array}$ & 3.19 & .394 \\
\hline Advertising products through a social media page shall increase sales & 3.36 & .482 \\
\hline $\begin{array}{l}\text { Based on my own experiences, one should advertise his/her products through using } \\
\text { social media }\end{array}$ & 3.47 & .771 \\
\hline $\begin{array}{l}\text { I advise the owners of all small-sized enterprises to make a social media page for } \\
\text { advertising their products }\end{array}$ & 3.38 & .721 \\
\hline
\end{tabular}

Based on table (6), the owners of small restaurants in Jordan have positive attitudes towards the role of social media page in achieving success for small-sized enterprises 
Table (7): Result related to human resources

\begin{tabular}{|l|c|c|}
\hline Statement & Mean & S.D \\
\hline Having qualified human resources is essential for advertising products effectively & 3.34 & .623 \\
\hline $\begin{array}{l}\text { The human resources needed for social media marketing include IT specialists and specialists in } \\
\text { communication networks, the Internet and application programs. }\end{array}$ & 3.31 & .464 \\
\hline Using social media as a marketing tool requires having a society that is ready for that. & 3.23 & .422 \\
\hline $\begin{array}{l}\text { The quality of the educational system is high and the society members are provided with } \\
\text { adequate opportunities to benefit from social media in e-commerce }\end{array}$ & 3.68 & .468 \\
\hline $\begin{array}{l}\text { Institutions -including educational institutions- provide students with many opportunities to use } \\
\text { ICT to develop human resources }\end{array}$ & 3.40 & .738 \\
\hline $\begin{array}{l}\text { The owners of small-sized enterprises must recruit human resources who are specialized in e- } \\
\text { commerce }\end{array}$ & 3.76 & .922 \\
\hline
\end{tabular}

Based on table (7), the owners of small restaurants in Jordan have positive attitudes towards the role of human resources in achieving success for small-sized enterprises. Based on tables (5), (6) and (7), the owners of small restaurant in Jordan have positive attitude toward using social media as a marketing tool. That is because all the means are greater than 3

\section{Hypotheses Testing:}

Analysis of variance (ANOVA) and the F-test were conducted for testing the main hypothesis. The t-test was conducted for testing the other hypotheses.

The main hypothesis:

Ha. Social media marketing has a statistically significant impact on the success of small-sized enterprises in Jordan.

Table (8): Results of Testing the Main hypothesis

\section{ANOVA}

\begin{tabular}{|ll|r|r|r|r|r|}
\hline \multicolumn{2}{|c|}{} & $\begin{array}{c}\text { Sum of } \\
\text { Sodel }\end{array}$ & & & & \\
\hline 1 & & Regression & df & Mean Square & F & Sig. \\
& Residual & 20.482 & 3 & 6.827 & 9.413 & $.000^{\mathrm{a}}$ \\
& Total & 90.628 & 96 & .725 & & \\
& 90.110 & 99 & & & \\
\hline
\end{tabular}

a. Predictors: (Constant), Human.Resources, Having.Website, Infrastructure

b. Dependent Variable: Small.Enterprises.Success

The F-test was conducted for testing the main hypothesis. Its results are presented in table 8 . It was found that the calculated $\mathrm{F}$ value is 9.413 which is greater than the tabulated $\mathrm{F}$ value (1.96). The significance value is 0.000. Based on these values, the main hypothesis is accepted. Thus, social media marketing has a statistically significant impact on the success of small-sized enterprises in Jordan. That means that using social media marketing tool shall enable the owners of small-sized enterprises in Jordan to achieve much success.

The First Sub-hypothesis

Ha.1: Electronic infrastructure has a statistically significant impact on the success of small-sized enterprises in Jordan

Table (9): Results of Testing the first sub-hypotheses

\section{Coefficients}

\begin{tabular}{|rl|r|r|r|r|r|}
\hline \multirow{2}{*}{ Model } & \multicolumn{2}{|c|}{$\begin{array}{c}\text { Unstandardized } \\
\text { Coefficients }\end{array}$} & \multicolumn{2}{c|}{$\begin{array}{c}\text { Standardized } \\
\text { Coefficients }\end{array}$} & & \\
\cline { 3 - 5 } & \multicolumn{1}{|c|}{$\mathrm{B}$} & \multicolumn{1}{c|}{ Std. Error } & \multicolumn{1}{|c|}{ Beta } & \multicolumn{1}{c|}{$\mathrm{t}$} & \multicolumn{1}{c|}{ Sig. } \\
\hline 1 & (Constant) & 2.989 & .526 & & 5.682 & .000 \\
& Infrastructure & .085 & .129 & .066 & .658 & .512 \\
\hline
\end{tabular}

a. Dependent Variable: Small.Enterprises.Success

In order to test the first sub-hypothesis, the t-test was conducted. The results of the latter test are presented in table (9). It was found that the calculated $t$ value is 0.658 . The latter value is less than the tabulated t value (1.98). The $\mathrm{F}$ value is .512. Based on these values, the first sub- hypothesis is rejected. Thus, electronic infrastructure doesn't have any statistically significant impact on the success of small-sized enterprises in Jordan 
The second sub-hypothesis:

Ho2. Having a social media page has a statistically significant impact on the success of small-sized enterprises in Jordan

Table (10): Results of Testing the Second Sub-hypothesis (2):

\section{Coefficients $^{\mathrm{a}}$}

\begin{tabular}{|c|c|c|c|c|c|c|}
\hline \multirow{2}{*}{\multicolumn{2}{|c|}{ Model }} & \multicolumn{2}{|c|}{$\begin{array}{c}\text { Unstandardized } \\
\text { Coefficients }\end{array}$} & \multirow{2}{*}{$\begin{array}{c}\text { Standardized } \\
\text { Coefficients }\end{array}$} & \multirow[b]{2}{*}{$t$} & \multirow[b]{2}{*}{ Sig. } \\
\hline & & $\mathrm{B}$ & Std. Error & & & \\
\hline & (Constant) & 4.516 & .418 & & 10.795 & .000 \\
\hline & Having.Website & -.302 & .104 & -.282 & -2.906 & .005 \\
\hline
\end{tabular}

a. Dependent Variable: Small.Enterprises.Success

The t-test was conducted to test the second sub-hypothesis. The results of the latter test are presented in table (10). It was found that the calculated $t$ value is 2.906 . The latter value is greater than the tabulated $t$ value (1.98). It was found that the $\mathrm{F}$ value is 0.00 . That means that the second sub-hypothesis is accepted. Thus, having a social media page has a statistically significant impact on the success of small-sized enterprises in Jordan The Third Sub-hypothesis:

Ho3: Human resources have a statistically significant impact on the success of small-sized enterprises in Jordan. Table (11): Results of Testing the Third Sub-hypothesis

\section{Coefficients $^{\mathrm{a}}$}

\begin{tabular}{|c|c|c|c|c|c|}
\hline \multirow[b]{2}{*}{ Model } & \multicolumn{2}{|c|}{$\begin{array}{l}\text { Unstandardized } \\
\text { Coefficients }\end{array}$} & \multirow{2}{*}{$\begin{array}{c}\text { Standardized } \\
\text { Coefficients } \\
\text { Beta }\end{array}$} & \multirow[b]{2}{*}{$\mathrm{t}$} & \multirow[b]{2}{*}{ Sig. } \\
\hline & B & Std. Error & & & \\
\hline $\begin{array}{ll}1 & \text { (Constant) } \\
& \text { Human.Resources }\end{array}$ & $\begin{array}{r}2.585 \\
.200\end{array}$ & $\begin{array}{l}.596 \\
.158\end{array}$ & .127 & $\begin{array}{l}4.337 \\
1.266\end{array}$ & $\begin{array}{l}.000 \\
.209\end{array}$ \\
\hline
\end{tabular}

a. Dependent Variable: Small.Enterprises.Success

The t-test was conducted for testing the third sub- hypothesis. The results of the latter test is presented in table (11). It was found that the calculated $t$ value is 1.266 . The latter value is less than the tabulated $t$ value (1.98). It was found that the F value is 0.209 . Based on these values, the third sub- hypothesis is rejected. That means that human resources don't have any statistically significant impact on the success of small-sized enterprises in Jordan.

\section{Conclusion}

It was found that the owners of small restaurants in Jordan have positive attitudes towards using social media as a marketing tool. It was found that the electronic infrastructure doesn't have any statistically significant impact on the success of small-sized enterprises in Jordan. It was found that having a social media page has a statistically significant impact on the success of small-sized enterprises in Jordan. It was found that human resources don't have any statistically significant impact on the success of small-sized enterprises in Jordan. It was found that using social media as a marketing tool has a statistically significant impact on the success of small-sized enterprises.

\section{The Recommendations}

The researcher recommends:

Improving the electronic infrastructure in Jordan. That shall enable the owners of small-sized enterprises to use social media effectively for advertising their products online.

Providing the employees at the marketing department of companies with training programs about social media, e-commerce and computer applications.

Providing human resources with attention. That's because human resources play a significant role in the process of advertising products through social media.

\section{References}

Al-Obeidi, A., Al-Mamouri, J., \& Ardi, J. (2011) The Effect of E-Commerce on Reducing Marketing Costs Applied Study in Zain Telecommunications Company,

Belkacem, A. (2003) The nature of electronic commerce and its various applications, Second Annual Scientific 
Conference of Information Technology and its Role in Economic Development, Faculty of Economics and Administrative Sciences, Al-Zaytoonah University.

Dahmash, N., \& Al-Qashi, Z. (2004), "The Suitability of the Accounting Profession for the E-Commerce Environment", Irbid Journal of Scientific Research, Volume 8, No. 2, Irbid National University.

ElAydi, H. (2018) The Effect of Social Media Marketing on Brand Awareness through Facebook: An IndividualBased Perspective of Mobile Services Sector in Egypt. Open Access Library Journal, 5, 1-5

McKinsey, T. (2007) How Businesses Are Using Web 2.0: A McKinsey Global Sur-vey. The McKinsey Quarterly. Benea, I., Alexandra (2014) Influences of Social Media on the Tourism and Hospitality Industry. Thesis Modul University Vienna .

Florez L,, Escobar M. , Restrepo A., Botero, D. (2018) nfluence of social networks on the purchase decisions of university students. Cuadernos de Gestión Vol. 18 - No 1, pp. 61-84.

Al-Jamal, S. (2015) The negative effects of smart phones on the behavior of students from the point of view of educational counselors and principals in the south of Hebron, the conference of smart devices in the emergence of children, Al Quds Open University 